\title{
Two new species of Moenkhausia Eigenmann (Characiformes: Characidae) from Serra do Cachimbo, Pará, Northern Brazil
}

\author{
Leandro M. Sousa, André L. Netto-Ferreira and José L. O. Birindelli
}

Two new species of Moenkhausia, one from the rio Tapajós and the other from the rio Xingu basins are described as apparently endemics of the Serra do Cachimbo. Both species, along with $M$. petymbuaba, share a distinct color pattern composed of large conspicuous dark blotches on the base of the body scales. Moenkhausia chlorophthalma, from rio Treze de Maio, a tributary to rio Curuá (rio Xingu basin), is distinguished by the presence of a proximal well delimited black area on the adipose fin and a green eye in life. Moenkhausia plumbea of the headwaters of tributaries of the rio Braço Norte, rio Tapajós basin is diagnosed by the presence of a dark longitudinal stripe across the eye and six branched pelvic-fin rays ( $v s$. seven). Relationships of the new species with other Moenkhausia are discussed.

Duas espécies novas de Moenkhausia, uma da bacia do rio Tapajós e outra da bacia do rio Xingu, são descritas como aparentemente endêmicas da Serra do Cachimbo. Ambas, juntamente com $M$. petymbuaba, compartilham um padrão de colorido exclusivo de grandes manchas escuras conspícuas na base das escamas do corpo. Moenkhausia chlorophthalma, do rio Treze de Maio, um afluente do rio Curuá (bacia do rio Xingu), é facilmente reconhecida pela presença de uma área preta bem delimitada na região anterior da nadadeira adiposa e possuir olhos verdes em vida. Moenkhausia plumbea ocorre nas cabeceiras dos afluentes do rio Braço Norte, bacia do rio Tapajós, e pode ser diagnosticada pela presença de uma faixa longitudinal escura no olho e seis raios ramificados na nadadeira pélvica (vs. sete). As relações entre as novas espécies com as demais Moenkhausia são discutidas.

Key words: Moenkhausia chlorophthalma, Moenkhausia plumbea, Moenkhausia petymbuaba, Taxonomy, Ostariophysi, Neotropical.

\section{Introduction}

In the first attempt to group the species of Moenkhausia into subunits, Géry (1977) recognized three assemblages within the genus based on Eigenmann’s (1917: 66-69) key to the species of Moenkhausia: the M. lepidura-group (shallow-bodied species with relatively few horizontal scale rows on the body); the $M$. grandisquamis-group (deepbodied species with relatively few horizontal scale rows); and the $M$. chrysargyrea-group (deep-bodied species with relatively numerous horizontal scale rows). Géry (1992) later focused his analysis to the $M$. lepidura-group especially to those species having a distinct dark mark on the upper lobe of caudal fin, independent of body depth or number of horizontal scale rows. Lucinda et al. (2007) recently described $M$. hysterosticta as a possibly member of that group. Costa (1994) did not follow Géry’s (1977) grouping, suggesting instead a new assemblage comprising $M$. oligolepis, $M$. pyrophthalma, and $M$. sanctaefilomenae. This group was defined by the presence of a distinct reticulate color pattern and a "black bar over the terminal portion of caudal peduncle and basal portion of caudal fin that is preceded by a light area on the caudal peduncle”. Lima \& Toledo-Piza (2001) described M. dyktiota as possibly related to this assemblage, and more recently two species were added to Costa's (1994) group: M. cosmops (Lima et al., 2007), and $M$. forestii (Benine et al., 2009).

Lima \& Birindelli (2006) described Moenkhausia petymbuaba, based on specimens collected in Serra do Cachimbo, which is the main geographical barrier between the middle courses of the rio Xingu and the rio Tapajós, where the headwaters of those drainages lie close to each other and are in some cases only separated by a few meters. Goulding et al. (2003) suggested a high level of endemism for the species from the Serra do Cachimbo, suggestion confirmed by subsequent collections (Birindelli et al., 2009a; Sabaj Pérez, 2009). The description of Jupiaba kurua (Birindelli et al., 2009b), and Leporinus guttatus (Birindelli \& Britski, 2009) from the rio Curuá provided evidence that the fish fauna upstream of the falls at Cachoeira da Serra was isolated from the rest of the drainage and is apparently highly endemic.

${ }^{1}$ Museu de Zoologia da Universidade de São Paulo, Caixa Postal 42494, 04218-970 São Paulo, SP, Brazil. Programa de Pós-Graduação em Ciências Biológicas (Zoologia)/IB-USP. leandro.m.sousa@gmail.com, alnferreira@gmail.com, josebirindelli@yahoo.com 
Two undescribed species of Moenkhausia, one from the rio Tapajós and another from the rio Xingu basins were discovered in small creeks located near the headwaters of the rio Curuá, with these portions isolated by large waterfalls from downstream portions of those systems. We herein describe both new species, discuss their possible relationships with congeners, and contribute to the understanding of the endemism in the Serra do Cachimbo.

\section{Material and Methods}

Counts and measurements follow Fink \& Weitzman (1974), Menezes \& Weitzman (1990) and Lima \& Birindelli (2006). All measurements were made point-to-point on the left side of the specimens whenever possible with dial calipers and data recorded to tenths of a millimeter. Standard length is presented in $\mathrm{mm}$, all other measurements are presented as proportions of standard length, except subunits of head wich are presented as proportions of head length. Meristic data are given in the description and are followed by the frequency for each count in parenthesis with an asterisk indicating counts of the holotype. Vertebrae, supraneurals, procurrent caudal-fin rays, branchiostegal rays, gill-rakers, teeth counts and numbers of teeth cusps were taken from cleared and stained paratypes (c\&s) prepared according to Taylor \& van Dyke (1985). Vertebrae of the Weberian apparatus were included in the precaudal counts as four elements, and the fused PU1+U1 was counted as a single element. Pattern of circuli and radii was defined on scales taken from the region between the lateral line and the dorsal-fin origin. Institutional abbreviations follow Ferraris (2007).

Dentary and premaxillary bones for Scanning Electron Micrographs (SEM) images were prepared by the following procedure: they were removed from cleared and double stained specimens, immersed in weak (less than $1 \%$ ) sodium hypochlorite solution and dried using successively more concentrated solutions of alcohol and, subsequently, acetone.

\section{Results}

\section{Moenkhausia chlorophthalma, new species Figs. 1-3}

Holotype. MZUSP 99412 (67.4 mm SL), Brazil, Pará, Altamira, rio Treze de Maio, tributary of rio Curuá, rio Iriri basin, rio Xingu drainage, 0845’06”S 5502'05”'W, 23 Jan 2009, A. L. Netto-Ferreira, J. L. Birindelli, L. M. Sousa \& P. Hollanda-Carvalho.

Paratypes. ANSP 188909 (5, 32.9-50.3 mm SL), AUM 50663 (5, 37.6-43.6 mm SL), INPA 33764 (5, 34.7-49.4 mm SL), MCP 44509 (5, 41.0-48.0 mm SL), MNRJ 35382 (5, 33.8-48.5 mm SL), MPEG 18327 (5, 37.9-52.9 mm SL) and MZUSP 101426 (81, 23.7-67.9 $\mathrm{mm}$ SL), same data as holotype. MZUSP 97092 (28, 38.0-64.8 mm SL, 2 c\&s, 43.3-49.6 mm SL), Brazil, Pará, Altamira, rio Treze de Maio, tributary of rio Curuá, rio Iriri basin, rio Xingu drainage, 0845’06”S 5502’05”W, 22 Nov 2007, J. L. Birindelli, L. M. Sousa, A. L. Netto-Ferreira, M. H. Sabaj Pérez \& N. K. Lujan.

Diagnosis. Moenkhausia chlorophthalma is distinguished from all congeners, except M. petymbuaba and M. plumbea by the presence of large dark blotches on the anterior to central portions of the scales forming the seven dorsalmost longitudinal series (vs. pigmentation absent or, when present, concentrated posteriorly along the border of the scales, and forming a reticulate pattern on the body). Moenkhausia chlorophthalma can be differentiated from both $M$. petymbuaba and M. plumbea by the possession of a proximal well-delimited black area on the adipose fin (vs. adipose fin with uniformly scattered dark chromatophores), 7 longitudinal rows of large dark blotches (vs. 8-9), 25-28 lateral line scales (vs. 33-36), 4 scales between the lateral line and the dorsal-fin origin (vs. 5), and 7-12 scales covering the anal-fin base (vs. 4-9). Moenkhausia chlorophthalma can be further separated from M. petymbuaba by lacking a conspicuous midlateral dark stripe ( $v s$. presence of

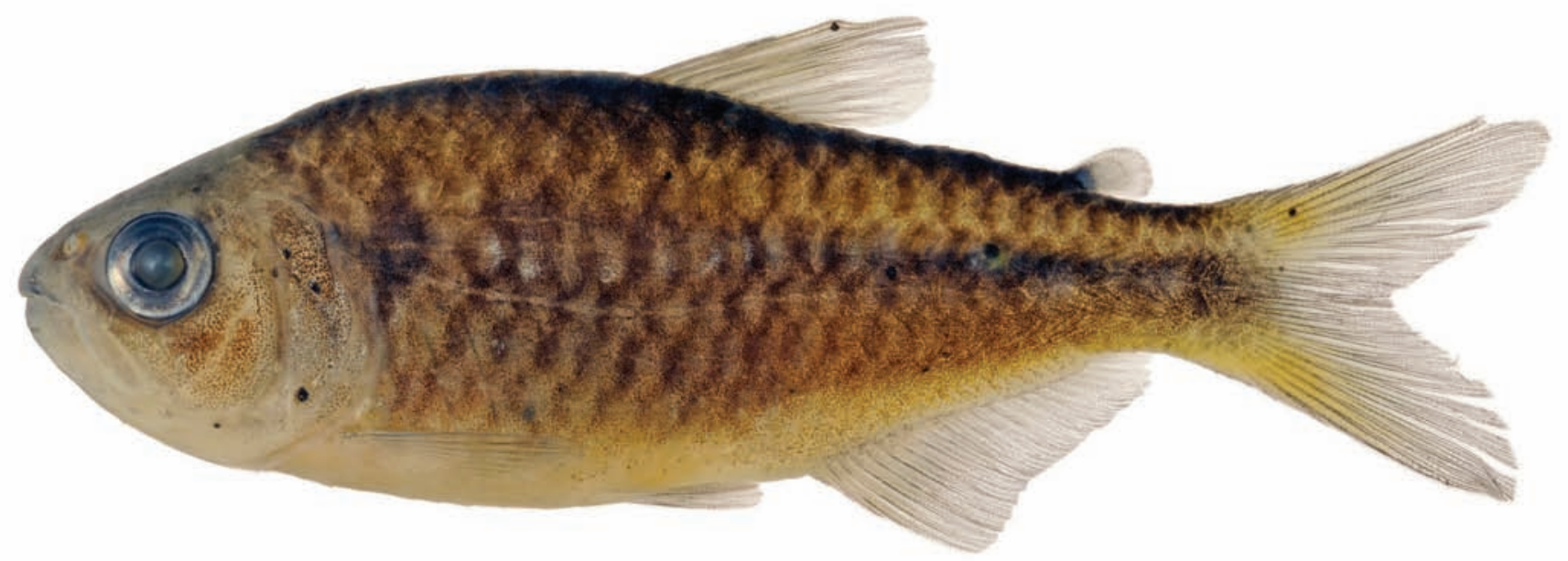

Fig. 1. Moenkhausia chlorophthalma, holotype, MZUSP 99412, 67.4 mm SL, Brazil, Pará, Altamira, rio Treze de Maio, tributary to rio Curuá, rio Iriri basin, rio Xingu drainage. 


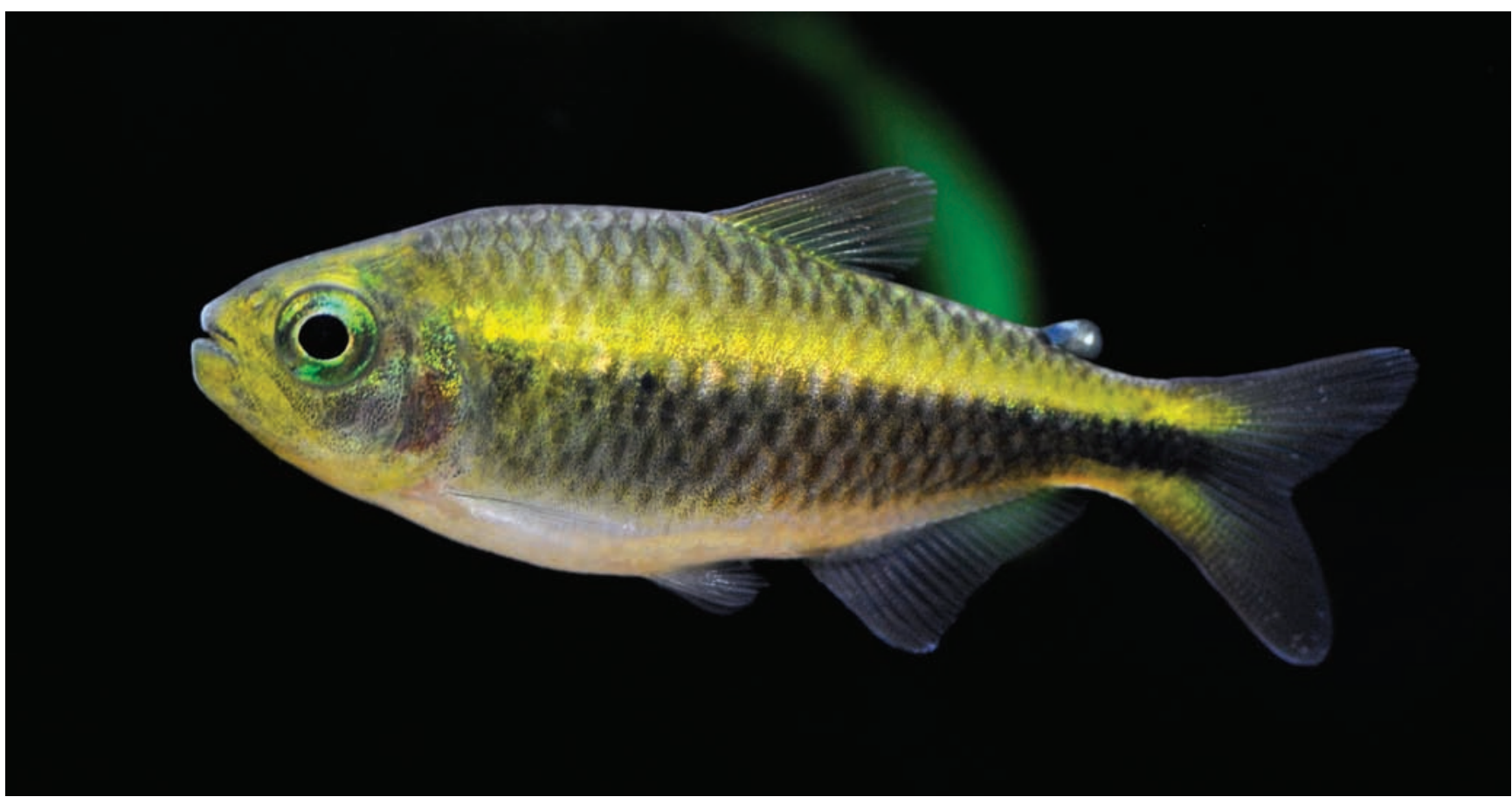

Fig. 2. Moenkhausia chlorophthalma, aquarium specimen showing live coloration, Brazil, Pará, Altamira, rio Treze de Maio, collected with holotype.

conspicuous midlateral dark stripe); and from M. plumbea by having 7 branched pelvic-fin rays ( $v s .6-7$ in specimens of M. plumbea examined).

Description. Morphometric data presented in Table 1. Overall size small (largest examined specimen $67.4 \mathrm{~mm}$ SL). Body compressed, moderately elongate. Greatest body depth located slightly anterior to dorsal-fin origin. Dorsal profile of head slightly convex from upper lip to vertical through nares; mostly straight from latter point to tip of supraoccipital spine; convex from tip of supraoccipital spine to dorsal-fin origin, straight from near of dorsal fin base to adipose fin; slightly concave between latter and origin of anteriormost dorsal procurrent caudal-fin ray. Ventral profile of head and body distinctly convex from lower lip to anal-fin origin; straight along anal-fin base, and concave between terminus of analfin and anteriormost procurrent caudal-fin ray.

Mouth terminal. Posterior limit of maxilla almost reaching vertical through middle of orbit. Premaxillary teeth in two rows (Fig. 3). Outer row with four (1) or six (1), relatively compressed, tricuspid teeth. Inner row with five (2) bulky tri- to pentacuspid teeth. Symphyseal tooth largest, asymmetrical, with single lateral cusp on anteromedial margin. Maxilla with three equal-sized tricuspid teeth. Dentary with four anteriormost teeth large, robust, pentacuspid, followed by a series of distinctly smaller, conic or tricuspid teeth. First gill arch with 1(2) hypobranchial, $8(2)$ ceratobranchial, 1(2) on cartilage between ceratobranchial and epibranchial, and 5(1) or 6(1) epibranchial gill-rakers. Branchiostegal rays 4(2), three originating on anterior ceratohyal and one on posterior ceratohyal.
Scales cycloid, with circuli absent on exposed area of scales, and few slightly divergent radii (usually less than 10) extending to posterior margin of scales. Lateral line slightly curved ventrally, completely pored, with 25(7), 26(10), $27 *(20)$ or $28(8)$ perforated scales. Horizontal scale rows between dorsal-fin origin and lateral line 4(45). Horizontal scale rows between lateral line and pelvic-fin insertion 4(45). Predorsal scales 7(16), 8*(10) or 9(4). Single row of 7(1), 8(1), $9 *(5), 10(12), 11(10)$ or 12(1) scales covering base of anteriormost anal-fin rays. Fourteen circumpeduncular

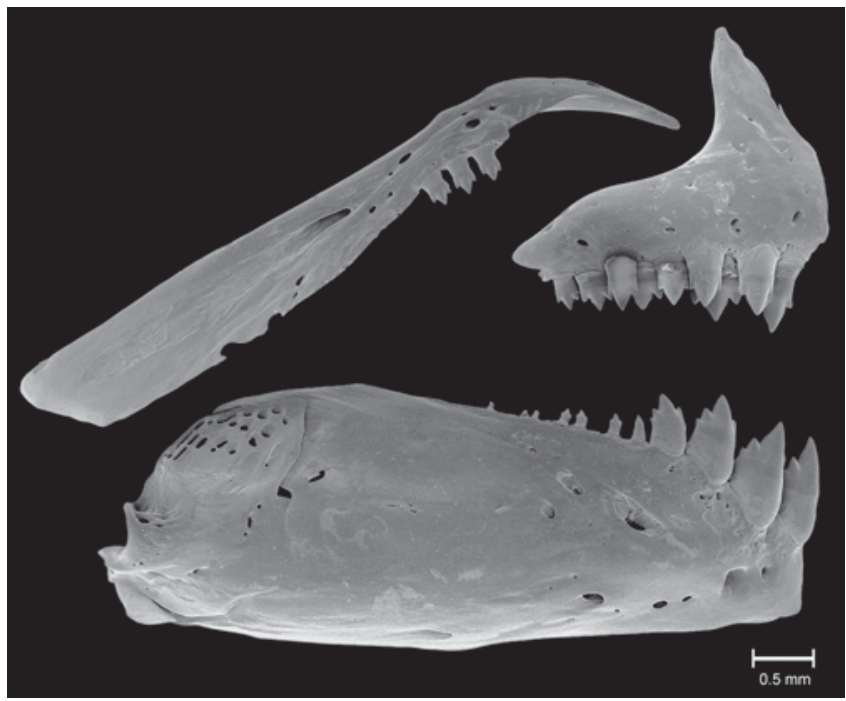

Fig. 3. Upper and lower jaws of Moenkhausia chlorophthalma, paratype, MZUSP 97092, 43.3 mm SL; lateral view, anterior to right, SEM preparation. 
Table 1. Morphometric data of Moenkhausia chlorophthalma. $\mathrm{N}=31, \mathrm{SD}=$ standard deviation.

\begin{tabular}{lcccc}
\hline & Holotype & Range & Mean & SD \\
\hline Standard length (mm) & 67.4 & $38.0-67.4$ & 47.0 & \\
$\quad$ Percents of standard lenght & & & & \\
Depth at dorsal-fin origin & 35.5 & $30.6-36.4$ & 33.2 & 1.5 \\
Snout to dorsal-fin origin & 53.4 & $51.9-56.9$ & 53.9 & 1.2 \\
Snout to pectoral-fin origin & 30.0 & $28.2-32.6$ & 30.0 & 0.9 \\
Snout to pelvic-fin origin & 49.1 & $46.1-51.7$ & 48.9 & 1.4 \\
Snout to anal-fin origin & 67.2 & $62.1-68.5$ & 65.3 & 1.6 \\
Caudal-peduncle depth & 12.0 & $10.2-13.0$ & 11.7 & 0.6 \\
Caudal peduncle length & 13.1 & $10.0-14.1$ & 12.0 & 0.9 \\
Pectoral-fin length & 21.1 & $17.7-23.1$ & 21.3 & 1.1 \\
Pelvic-fin length & 14.7 & $14.0-15.8$ & 14.9 & 0.6 \\
Dorsal-fin base length & 14.2 & $13.2-15.3$ & 14.0 & 0.6 \\
Dorsal-fin length & 25.1 & $21.2-27.2$ & 25.1 & 1.3 \\
Anal-fin base length & 25.5 & $24.5-28.1$ & 26.5 & 0.9 \\
Anal-fin lobe length & 16.3 & $15.3-19.8$ & 17.6 & 1.0 \\
Eye to dorsal-fin origin & 38.7 & $35.8-40.4$ & 37.9 & 1.0 \\
Dorsal-fin origin to caudal-fin base & 51.8 & $46.6-53.7$ & 51.0 & 1.3 \\
Bony head length & 29.8 & $27.4-31.3$ & 29.7 & 1.0 \\
$\quad$ Percents of head length & & & & \\
Horizontal eye diameter & 30.8 & $30.6-39.6$ & 36.0 & 2.5 \\
Snout length & 27.4 & $23.9-29.2$ & 26.9 & 1.4 \\
Least interorbital distance & 33.8 & $28.9-37.3$ & 32.8 & 1.8 \\
Upper jaw length & 54.7 & $50.6-56.0$ & 53.2 & 1.2 \\
\hline
\end{tabular}

scales. Caudal-fin scaled on proximal one-fifth of upper and lower caudal-fin lobes.

Pectoral-fin rays i, $10(15)$ or $11^{*}(15)$. Tip of pectoral fin reaching vertical through pelvic-fin origin. Pelvic-fin rays $i$, 7. Supraneurals 5(2). Dorsal-fin rays ii, 9(46). Dorsal-fin origin situated slightly posterior to middle of standard length. Base of posteriormost dorsal-fin ray located at vertical through anal-fin origin. First dorsal-fin pterygiophore inserted posteriorly to neural spine of $10^{\text {th }}$ vertebra (2). Adipose fin present. Anal-fin rays iii, 19(1); iii, 20(1); iv, 18(2); iv, 19*(12); iv, 20(19); iv, 21(3); iv, 22(1); v, 19(1); v, 20(2) or v, 21(1). Anteriormost anal-fin pterygiophore inserted behind haemal spine of $17^{\text {th }}(2)$ vertebra. Caudal-fin forked, lobes slightly rounded, similar in size. Principal caudal-fin rays i,9+8,i. Dorsal procurrent caudal-fin rays 13(2) and ventral procurrent caudal-fin rays $9(1)$ or $11(1)$. Total vertebrae $34(1)$ or 35(1), with 16(1) or 17(1) precaudal and 18(2) caudal vertebrae.

Color in alcohol. Ground color tan, with chromatophores densely covering entire body, except for ventral portion. Lower lip, snout, top of head and dorsal portion of body darkly pigmented, resulting in overall countershaded color pattern. Edge of upper lip dark. Inconspicuous humeral blotch present, vertically elongated. Seven dorsalmost longitudinal scale rows with scales bearing large dark blotches anterior to center of each, with blotch fading towards scale border. Longitudinal, broad, dark midlateral stripe slightly curved ventrally, extending from pectoral girdle to tip of middle caudal-fin rays. Stripe diffuse, formed by scattered chromatophores. Dorsal, caudal, anal, and pectoral fins hyaline, with small scattered chromatophores. Adipose fin with proximally well-delimited dark area (Fig. 1).

Color in life. Ground color of dorsal portion of body yellow to greenish, with iridescent midlateral yellow stripe and large, dark, ventrally curved longitudinal stripe immediately ventral to it, stripe extending from humeral region to caudal peduncle. Abdominal region white to light yellow. Eye bright green. Middle caudal-fin rays with dark mark, anteriorly delimited by dorsal and ventral yellowish areas (Fig. 2).

Etymology. From the Greek chloros, meaning green, and ophthalmos, meaning eye, in reference to the iridescent green eyes in live specimens. An adjective.

Distribution. Known from type-locality (Figs. 4 and 5).

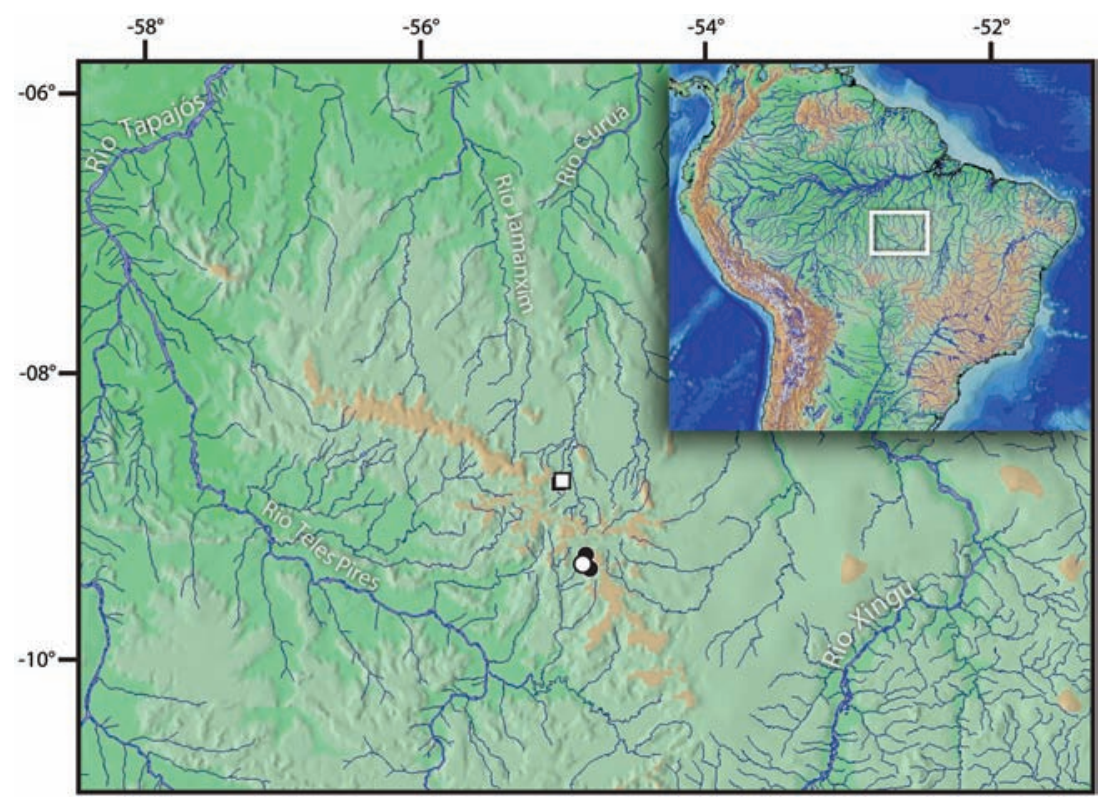

Fig. 4. Collecting sites and type-localities of Moenkhausia chlorophthalma (squares) and Moenkhausia plumbea (circles). Open symbols represent type-localities. 

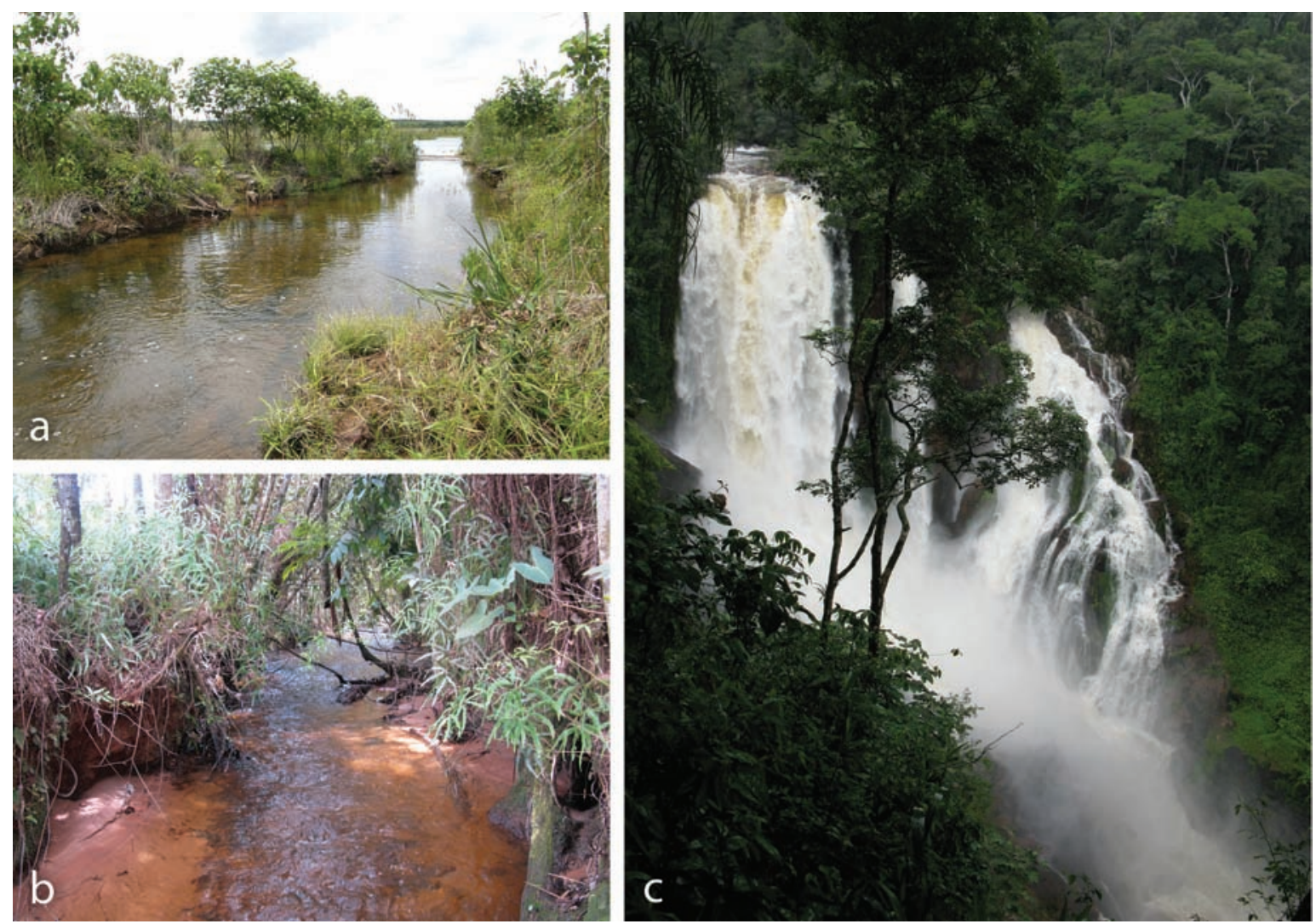

Fig. 5. Habitats at Serra do Cachimbo: a - type-locality of Moenkhausia chlorophthalma, rio Treze de Maio, tributary of rio Curuá, rio Xingu basin, 0845'06”S 5502'05”W; b - type-locality of Moenkhausia plumbea, a tributary of rio Braço Norte,

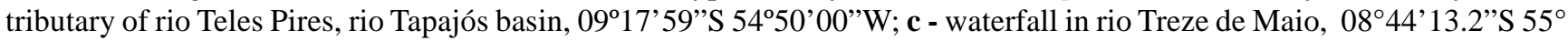
01’51.9”W.

\section{Moenkhausia plumbea, new species} Figs. 6-9

Holotype. MZUSP 99415 (49.5 mm SL), Brazil, Pará, Novo Progresso, tributary to rio Braço Norte, at bridge of BR 163 road near Air Force Base, rio Peixoto de Azevedo, rio Teles Pires drainage, rio Tapajós basin; 09¹7’59”S 5450’00”W, 22 Jan 2009; A. L. NettoFerreira, J. L. Birindelli, L. M. Sousa \& P. Hollanda-Carvalho.

Paratypes. All from Brazil, Pará, Novo Progresso. ANSP 188911 (5, 35.1-44.8 mm SL), AUM 50664 (5, 34.3-41.2 mm SL), INPA 33765 (5, 35.5-43.7 mm SL), MCP 44510 (5, 32.8-44.2 mm SL), MNRJ 35384 (5, 37.7-46.3 mm SL), MPEG 18328. (5, 32.3-40.9 mm SL), MZUSP 96849 (14, 34.0-51.2 mm SL, 2 c\&s, 39.1, 42.0 mm SL), tributary of rio Braço Norte, rio Peixoto de Azevedo, rio Teles Pires basin, rio Tapajós drainage, 09¹9’17’S 5450’26”W, 10 Nov 2007, J. L. Birindelli, L. M. Sousa, A. L. Netto-Ferreira, M. H. Sabaj Pérez \& N. K. Lujan. MZUSP 101435 (24, 20.4-45.9 mm SL), same locality as ANSP 188911, 22 Jan 2009, A. L. Netto-Ferreira, J. L. Birindelli, L. M. Sousa \& P. Hollanda-Carvalho. MZUSP 101436 (1, 15.6 mm SL), tributary of rio Braço Norte, at bridge of BR 163 road, near the Air Force Base, rio Peixoto de Azevedo, rio Teles Pires basin, rio Tapajós drainage, 09²1'55”'S 5450’00”W, 22 Jan 2009, A. L. NettoFerreira, J. L. Birindelli, L. M. Sousa \& P. Hollanda-Carvalho. MZUSP 101439 (10, 30.1-49.3 mm SL), collected with holotype.

Diagnosis. Moenkhausia plumbea is distinguished from all congeners, except $M$. chlorophthalma and M. petymbuaba, by the presence of large dark blotches on the anterior to the central portions of each scale along the seven dorsalmost longitudinal series ( $v s$. pigmentation absent or, when present, concentrated posteriorly along the border of scales and forming a reticulate pattern in the body). Moenkhausia plumbea differs from both $M$. petymbuaba and $M$. chlorophthalma in possessing a dark longitudinal stripe along the eye; and is further separated from M. petymbuaba in lacking a very conspicuous dark midlateral stripe; and from $M$. chlorophthalma in possessing eight or nine longitudinal rows of large dark blotches (vs. seven), 33-36 lateral line scales (vs. 25-28), five scales between lateral line and dorsal fin ( $v s$. four), 4-9 anal-fin base scales (vs. 7-12), and usually 6 branched pelvic-fin rays (vs. 7).

Description. Morphometric data presented in Table 2. Overall size small (largest examined specimen $49.7 \mathrm{~mm} \mathrm{SL}$ ). Body compressed, moderately elongate. Greatest body depth located slightly anterior to dorsal-fin origin. Dorsal profile of head slightly convex from upper lip to vertical through nares; somewhat straight from latter point to tip of supraoccipital spine; convex from tip of supraoccipital spine to dorsal-fin origin, straight from dorsal fin terminus to adipose fin; slightly concave between latter point and origin of anteriormost dorsal procurrent caudal-fin ray. Ventral profile of head and body distinctly convex from lower lip to pelvic-fin origin; straight from latter point to anal-fin origin, and 
along anal-fin base; concave between terminus of anal-fin and anteriormost procurrent caudal-fin ray.

Mouth terminal. Terminus of maxilla located slightly posterior to vertical through anterior margin of orbit. Premaxillary teeth in two rows (Fig. 8). Outer row with 5(2), relatively compressed, tricuspid teeth. Inner row with 5(2) robust pentacuspid teeth; Symphyseal tooth largest, slightly asymmetrical, with medialmost cusp greatly reduced. Maxilla with two tricuspid equally developed teeth. Dentary with 12(1) or 15(1) teeth; 4 or 5 anteriormost teeth larger, robust, pentacuspid, posterior ones conic, penta- or tricuspid, distinctly smaller. First gill arch with 2(2) hypobranchial, 8(2) ceratobranchial, 1(2) cartilage between ceratobranchial and epibranchial, and 6(2) epibranchial gill-rakers. Branchiostegal rays $4(2)$. Three rays originating on anterior ceratohyal and one on posterior ceratohyal.

Scales cycloid, circuli absent on exposed portion of scales, with few (usually up to 15) slightly divergent radii extending to posterior margin of scales. Lateral line slightly

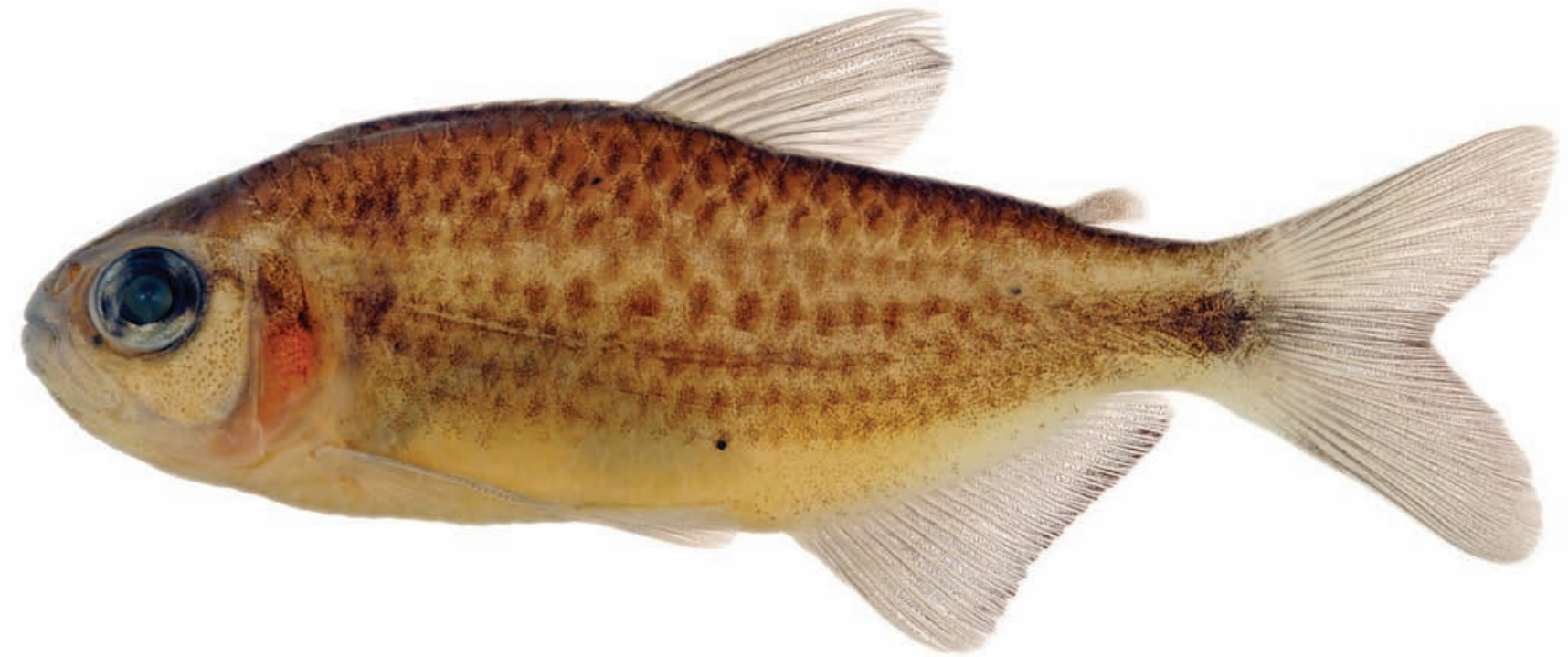

Fig. 6. Moenkhausia plumbea, holotype, MZUSP 99415, 49.5 mm SL, Brazil, Pará, Novo Progresso, tributary to rio Braço Norte, at bridge of BR 163 road near Air Force Base, rio Tapajós basin.

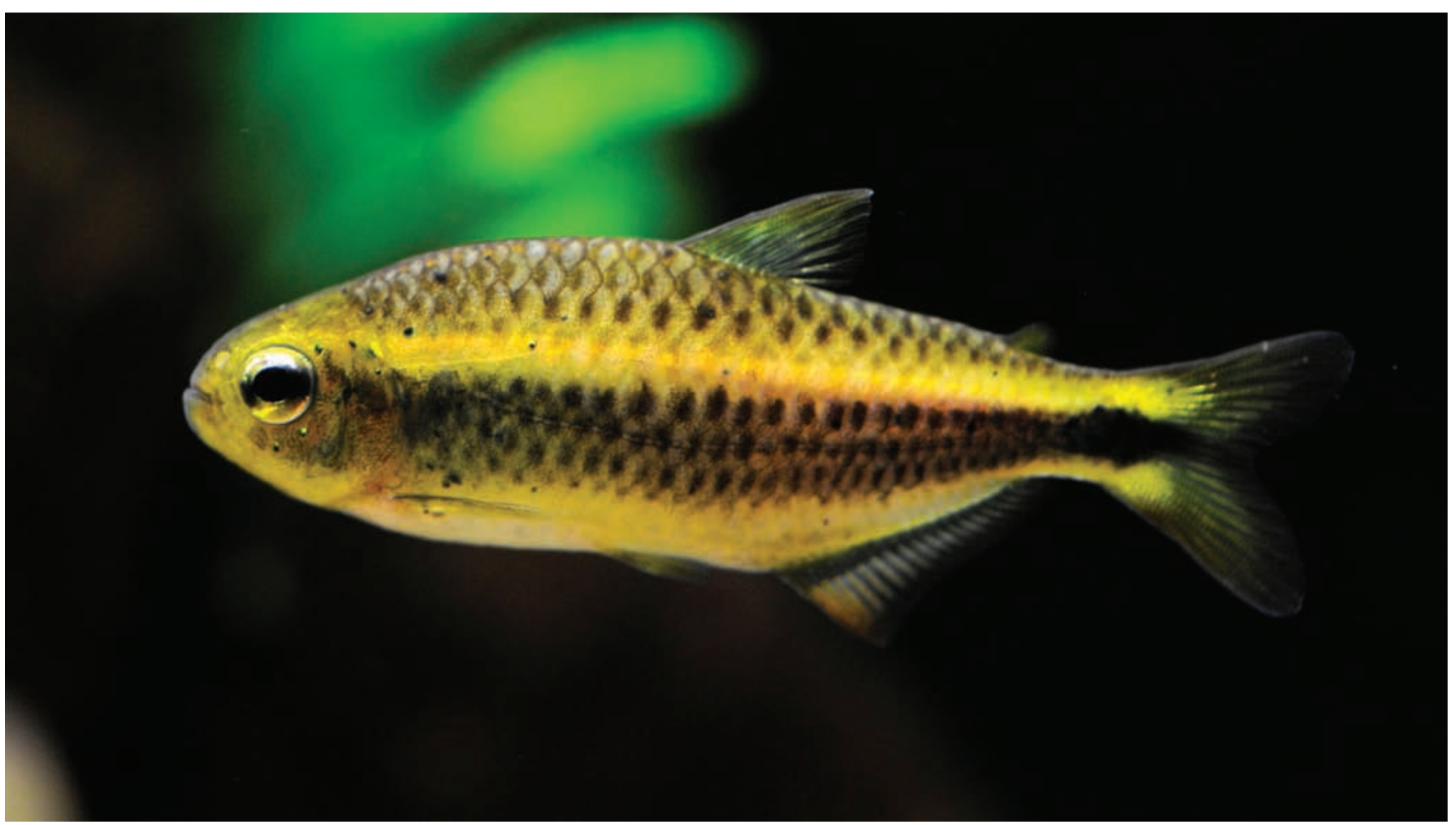

Fig. 7. Moenkhausia plumbea, aquarium specimen showing live coloration from Brazil, Pará, Novo Progresso, tributary of rio Braço Norte, rio Tapajós basin, collected with MZUSP 96849. 


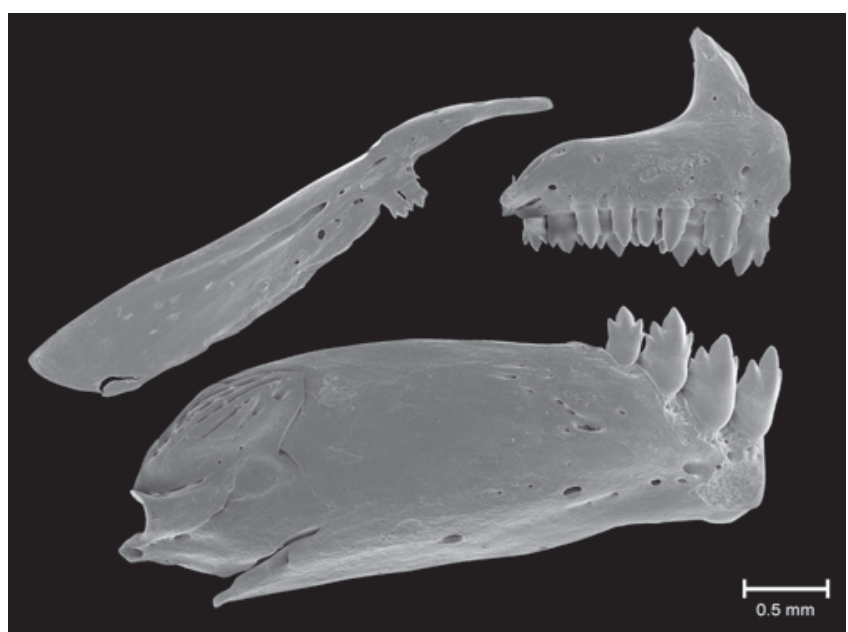

Fig. 8. Upper and lower jaws of Moenkhausia plumbea, paratype, MZUSP 96849, $39.1 \mathrm{~mm}$ SL; lateral view, anterior to right. Retroarticular and posterior, smaller teeth of dentary lost during SEM preparation.

curved ventrally, completely pored, with 33(3), 34*(8), 35(11), 36(7) or 37(1) perforated scales. Horizontal scale rows between dorsal-fin origin and lateral line 5. Horizontal scale rows between lateral line and pelvic-fin insertion 4 . Predorsal scales $9(5), 10 *(24)$ or $11(1)$. Single row of $5^{*}(7), 6(17), 7(4), 8(1)$ or 9(1) scales covering base of anteriormost anal-fin rays. Caudal peduncle with 14 circumpeduncular scales. Caudal fin scaled, scales present on proximal one-fifth of upper and lower caudalfin lobes.

Pectoral-fin rays i, 8(1), 9(13) 10*(15) or 11(1). Tip of pectoral fin almost reaching vertical through pelvic-fin origin. Pelvicfin rays i, $6 *(32)$, 7(2). Supraneurals 4(1) or 5(1). Dorsal-fin rays ii (1) or iii (1), 7(1), 8(2) 9*(27), with first unbranched ray reduced in size. Dorsal-fin origin located slightly posterior to middle of standard length. Base of posteriormost dorsal-fin ray situated at vertical through anal-fin origin. First dorsal-fin pterygiophore inserted posterior to neural spine of $10^{\text {th }}$ vertebra (2). Adipose fin present. Anal-fin rays iii, 20(1); iv, 18(6); iv, 19(3); iv, 20(17); iv, 21(10); iv, 22*(2); v, 19(1) or v, 20(4). Anteriormost anal-fin pterygiophore inserted behind haemal spine of $17^{\text {th }}$ vertebra (2). Caudal fin forked, lobes slightly rounded and similar in size. Principal caudal-fin rays 10+9. Ten (2) dorsal procurrent and nine (2) ventral procurrent caudal-fin rays. Total vertebrae 35(1) or 36(1) with 17(2) precaudal and 18(1) or 19(1) caudal vertebrae.

Color in alcohol. Ground color tan, with chromatophores densely covering whole body, except for abdomen and along distinct unpigmented area extending from eye to caudal peduncle and forming light midlateral stripe. Lower lip, snout, top of head and dorsal portion of body densely covered by small dark chromatophores, resulting in overall countershaded color pattern. Margin of upper lip dark. Vertically elongate humeral blotch present but inconspicuous. Eight or nine dorsalmost longitudinal scale rows with scales bearing large dark blotches on anterior to central portions but fading towards scale margin. Broad, dark, slightly concave midlateral stripe extending from pectoral girdle to tip of median caudal-fin rays. Stripe diffuse, formed by scattered chromatophores. Dorsal, caudal, anal, and pectoral-fins hyaline, with small few chromatophores. Adipose fin dusky, with scattered small chromatophores (Fig. 6).

Color in life. Ground color yellowish, with distinct clear midlateral yellow stripe and large, dark, ventrally curved longitudinal stripe immediately ventral to it. Stripes run from humeral region to caudal peduncle. Abdomen white to light yellow. Eye clear, with longitudinal dark stripe. Caudal fin with middle dark stripe delimited anteriorly by upper and lower yellowish areas. Specimens kept in captivity for several months have dorsal and anal fins lightly pigmented with gradients of green, yellow and red (Fig. 7).

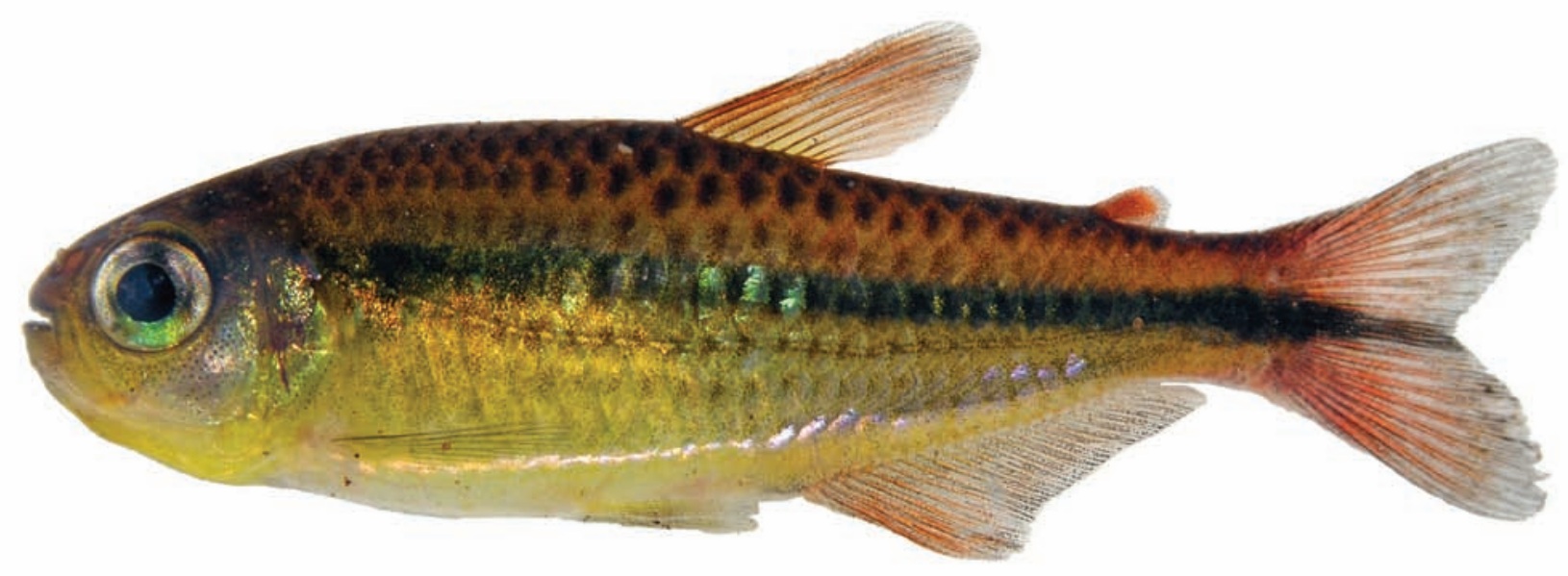

Fig. 9. Moenkhausia petymbuaba, photographed alive, MZUSP 97530, Brazil, Pará, Altamira, tributary to rio Curuá, rio Xingu basin. Photo by M. Sabaj Pérez. 
Etymology. From the Latin plumbum, meaning lead, in allusion to the color of the midlateral stripe below the unpigmented stripe in live specimens. An adjective.

Distribution. Known from headwaters of tributaries of the rio Braço Norte (rio Tapajós basin) in the Serra do Cachimbo (Figs. 4 and 5).

Table 2. Morphometric data of Moenkhausia plumbea. $\mathrm{N}=32$, $\mathrm{SD}=$ standard deviation.

\begin{tabular}{lcccc}
\hline & Holotype & Range & Mean SD \\
\hline Standard length (mm) & 49.7 & $34.0-49.7$ & 40.1 & \\
$\quad$ Percents of standard lenght & & & & \\
Depth at dorsal-fin origin & 32.2 & $30.0-37.5$ & 33.4 & 1.6 \\
Snout to dorsal-fin origin & 52.9 & $51.8-56.5$ & 53.3 & 1.0 \\
Snout to pectoral-fin origin & 27.0 & $25.3-29.8$ & 27.3 & 1.1 \\
Snout to pelvic-fin origin & 46.5 & $44.2-49.3$ & 46.3 & 1.3 \\
Snout to anal-fin origin & 62.0 & $60.7-65.3$ & 63.3 & 1.2 \\
Caudal-peduncle depth & 10.9 & $10.3-12.5$ & 11.2 & 0.5 \\
Caudal peduncle length & 13.3 & $10.5-14.5$ & 12.5 & 1.0 \\
Pectoral-fin length & 19.3 & $17.6-22.4$ & 20.2 & 1.2 \\
Pelvic-fin length & 14.1 & $13.8-16.8$ & 15.1 & 0.8 \\
Dorsal-fin base length & 12.9 & $12.0-14.3$ & 13.0 & 0.6 \\
Dorsal-fin length & 24.7 & $23.3-29.4$ & 26.2 & 1.7 \\
Anal-fin base length & 28.4 & $26.6-30.7$ & 28.3 & 1.0 \\
Anal-fin lobe length & 15.9 & $15.9-21.7$ & 18.7 & 1.2 \\
Eye to dorsal-fin origin & 39.4 & $37.3-42.6$ & 39.3 & 1.0 \\
Dorsal-fin origin to caudal-fin base & 51.1 & $50.2-54.2$ & 52.2 & 1.0 \\
Bony head length & 26.6 & $23.8-28.1$ & 26.1 & 1.0 \\
$\quad$ Percents of head length & & & & \\
Horizontal eye diameter & 33.3 & $33.3-40.8$ & 37.9 & 1.9 \\
Snout length & 25.8 & $23.5-27.7$ & 25.5 & 1.0 \\
Least interorbital distance & 34.8 & $32.5-36.7$ & 34.6 & 1.0 \\
Upper jaw length & 48.5 & $42.6-48.5$ & 45.7 & 1.4 \\
\hline
\end{tabular}

\section{Discussion}

Even though the monophyly of Moenkhausia is yet to be demonstrated, the species described herein display the features proposed by Eigenmann (1917) to define that genus. Among their congeners, $M$. chlorophthalma, M. plumbea, and $M$. petymbuaba are the only species with a color pattern composed of large dark blotches on the scales of seven to nine dorsalmost longitudinal scale series. Pigmented scales are also observed in species currently assigned to the $M$. oligolepis/M. sanctaefilomenae group and M. diamantina. However, in those species, the pigmentation is concentrated on the distal border of the scales, thereby forming a dark reticulate pattern on the body. Benine (2002) states that $M$. nigromarginata also has a reticulate pattern, but Costa (1994) did not consider the species as demonstrating this feature. Examination of type specimens of M. nigromarginata similarly failed to confirm Benine's (2002) observation. Moenkhausia cotinho, which was nested within the $M$. oligolepis/M. sanctaefilomenae group by Benine (2002), also has blotches at the bases of the scales, but differs from M. chlorophthalma, M. plumbea, and M. petymbuaba by having small dark patches on the third and fourth longitudinal series above the lateral line, and having a reticulate pattern on the scales below the lateral line series.

Benine (2002) proposed the presence of laminar expansions of the ectopterygoid and the palatine as derived osteological characters for grouping $M$. levidorsa, $M$. sanctaefilomenae, M. oligolepis, M. cotinho, and $M$. grandisquamis. Those expansions are variably developed in the two new species described herein, $M$. petymbuaba and all other species of Moenkhausia examined (see "examined material"). Thus, such a range of variation of those characters may constitute synapomorphies for a broader group within Moenkhausia.

As discussed by Lima \& Zuanon (2004), the dark midlateral stripe in small characids can be categorized (without implied homology) as narrow and straight (e.g., Hyphessobrycon cachimbensis Travassos and Moenkhausia petymbuaba); broad and straight (e.g., Moenkhausia phaenota Fink, and Moenkhausia heicoi Géry \& Zarske), or broad and curved (e.g., Nematobrycon and Inpaichthys). Moenkhausia plumbea and M. clorophthalma have a broad and ventrally curved dark midlateral stripe somewhat similar to Nematobrycon and Inpaichthys except in being more diffuse.

Mirande (2009) recently criticized the uncritical acceptance of the taxonomic scheme for characids, based on Eigenmann's (1917) criteria and perpetuated by Géry (1977). Although a few species of Moenkhausia were included in Mirande's phylogenetic study, both analyses performed by the author refute the monophyly of the genus. In the weighted parsimony hypothesis, Moenkhausia is paraphyletic, with Bario as sister taxon to $M$. sanctaefilomenae, occupying the distalmost position in the clade. In the unweighted hypothesis, the species of Moenkhausia are recovered in two clades included in a large policotomy, with $M$. sanctaefilomenae as the sister taxon of Bario in one of the clades, corroborating Benine (2004). However, the synapomorphies of this and all the clades located distally to node 203 (except node 220, the “Jupiaba clade") are not listed in his appendix 3 , due to a composition error in the final version of the manuscript (Mirande, pers. comm.). Our examinations suggest that Moenkhausia clorophthalma and M. plumbea appear to be closely related to $M$. petymbuaba based on the shared presence of dark blotches on the base of body scales. Nevertheless, the relationships between these species and congeners are obscure, and the group proposed herein does not conform to any previously proposed species group within the genus.

The discovery of related species of Moenkhausia endemic to tributaries of both the rio Xingu and rio Tapajós basins on the highest portion of the Serra do Cachimbo highlights the complexity of the river drainages in the area. Apparently, $M$. clorophthalma, M. petymbuaba and M. plumbea have rather restricted distributions, and do not occur sympatrically. This scenario indicates that the increase in collection efforts, especially in similar creeks of isolated drainages, may result in the discovery of additional endemic species of Moenkhausia and other genera.

Comparative material. Astyanax sp.: MZUSP 28140 (2 c\&s, 41.3$67.2 \mathrm{~mm}$ SL), small stream tributary to riacho do Palácio, São Francisco basin, Santana do Riacho, Minas Gerais, 19¹0’S 
434'' W. Hemigrammus unitaeniatus: MZUSP 38713 (1 c\&s, 34.5 $\mathrm{mm} \mathrm{SL}$ ), first tributary to rio Tarapuy, río Negro, Napo, Equador. Hyphessobrycon compressus: MZUSP 28535 (1c\&s, 22.4 mm SL), Baba Creek near New Lagoon River, Orengewalk, Belize, 1746’44”N 88`38'29'W. Jupiaba iasy: MZUSP 97441 (21, 26.0-40.1 mm SL, 4 c\&s, 32.0-40.1 mm SL), Pará, Novo Progresso, rio Jamanxim, rio Tapajós drainage, sandy beach close to Novo Progresso, 0703'52”S 5526'28”'W. Jupiaba kurua: MZUSP 96857, paratypes (70, 51.986.0 mm SL, 5 c\&s, 56.4-77.6 mm SL), rio Curuá, rio Iriri basin, Altamira, Pará, 0846’09”S 5457’02”W; MZUSP 97105, paratypes (60, 45.9-82.3 mm SL, 1 c\&s, 69.1 mm SL), rio Curuá, rio Iriri basin, Altamira, Pará, 0842’28”S 5457’12”W. Jupiaba paranatinga: MZUSP 95720 (3 c\&s, 34.1-37.6 mm SL), rio Teles Pires, Paranaíta, Mato Grosso, 09²7’07”S 56³0’46”W. Moenkhausia cosmops: MZUSP 93494, holotype (43.1 mm SL), córrego 25 de Maio, tributary to rio Papagaio, rio Tapajós basin, Sapezal, Mato Grosso. MZUSP 93556 (3 c\&s, 26.3-28.6 mm SL), rio Juruena, rio Tapajós basin, Sapezal, Mato Grosso, 13¹4’47”S 5900’52”W. Moenkhausia cf. cotinho: MZUSP 7274 (9, 51.7$59.9 \mathrm{~mm}$ SL), small stream tributary to rio Maraú, Maués, Amazonas, 03²4'S 57²2’W; MZUSP 97450 (2, 28.6-44.8 mm SL), rio Jamanxim, rio Tapajós basin, Novo Progresso, Pará, 0703’52',S 5526’28'”W; MZUSP 62137 (1 c\&s, 36.3 mm SL), rio Negro, Santa Isabel do Rio Negro, Amazonas, $00^{\circ} 31^{\prime} \mathrm{S} 65^{\circ} 01^{\prime} \mathrm{W}$; MZUSP 100593 (2, 47.9-51.3 mm SL), rio Aripuanã, downstream to Dardanelos/Andorinhas rapids, Aripuanã, Mato Grosso. Moenkhausia diamantina: MZUSP 49236 (3, 22.0-27.8 mm SL), rio Una, rio Paraguaçu basin, Boa Vista do Tupim, Bahia, $12^{\circ} 58^{\prime} \mathrm{S}$ 4057’ W; MZUSP 86132 (1, 40.6 mm SL), rio Paraguaçu, upstream of city, Itaetê, Bahia, 1258'25'’S 4058'20'’W. Moenkhausia diktyota: MZUSP 62614, holotype (51.4 mm SL), small stream near Tapurucuara, Amazonas; MZUSP 93414 (1, 42.8 mm SL), small stream on Ramal 1, road to Cucuí, São Gabriel da Cachoeira, Amazonas, 0008'S 6705’W. Moenhkausia lopesi: MZUSP 82057 (1 c\&s, 32.9 mm SL), ribeirão Comprido, tributary to rio Corrente, Sonora, Mato Grosso do Sul. Moenkhausia nigromarginata: MZUSP 45289, paratypes (5, 20.9-39.8 mm SL), small stream tributary to rio Cravari, near road MT-170, Mato Grosso. Moenkhausia oligolepis: MZUSP 96201 (50, 28.3-53.8 mm SL), rio Teles Pires, Paranaíta, Mato Grosso, 09²7’31”S 56²9’19”W. Moenkhausia petymbuaba: MZUSP 66681, paratypes (2 c\&s, 22.233.4 mm SL), rio Curuá, Altamira, Pará, 0844’S 5457’W; MZUSP 97530, 335, tributary to rio Curuá, rio Iriri basin, Altamira, Pará, 0847’03”S 5458'29”W; Moenkhausia pyrophthalma: MZUSP 43372 (2, 24.3-25.8 m SL), left margin of rio Tocantins $500 \mathrm{~m}$ from bridge, Porto Nacional, Tocantins, $10^{\circ} 43^{\prime} \mathrm{S} 48^{\circ} 25^{\prime} \mathrm{W}$; MZUSP 45290, paratypes (7, 20.1-29.5 mm SL), stream crossing road between Água Boa and Cocalinho, rio Tocantins basin, Mato Grosso,

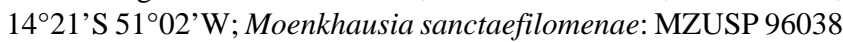
(3 c\&s, 29.9-39.3 mm SL), rio São Francisco basin, Bahia; MZUSP 103756 (2, 27.1-37.6 mm SL), córrego Aldeia, Alto Taquari basin, Coxim, Mato Grosso do Sul, 18²8'50', S 5440’37', W. Tetragonopterus chalceus: MZUSP 36814 (1 c\&s, 47.9 mm SL), rio Xingu, Pará, $03^{\circ} 48^{\prime} \mathrm{S} 52^{\circ} 32^{\prime} \mathrm{W}$.

\section{Acknowledgements}

We are grateful to Manoela M. F. Marinho, Mario C. C. de Pinna and Naércio A. Menezes for valuable comments and suggestions on the manuscript. Specimens were collected during the PIPE expedition to Serra do Cachimbo, a joint collaboration of MZUSP, ANSP, and AUM, funded by the All Catfish Species Inventory (NSF DEB-0315963). We are grateful to Mark Sabaj Pérez, Nathan Lujan and Pedro HollandaCarvalho for their help and assistance during field expeditions. Authors were supported by FAPESP (fellowships 06/041615-ALNF, 06/53737-7-JLOB and 06/04162-1-LMS).

\section{Literature Cited}

Benine, R. C. 2002. Moenkhausia levidorsa, a new species from rio Aripuanã, Amazon basin, Brazil (Characiformes: Characidae). Ichthyological Exploration of Freshwaters, 13(4): 289-294.

Benine, R. C. 2004. Análise filogenética do gênero Moenkhausia Eigenmann, 1903 (Characiformes: Characidae) com uma revisão dos táxons do alto rio Paraná. Unpublished M.Sc. Dissertation, Universidade Estadual Paulista, Botucatu, 317p

Benine, R. C., T. C. Mariguela \& C. Oliveira. 2009. New species of Moenkhausia with comments on the Moenkhausia oligolepis species complex. Neotropical Ichthyology, 7(2): 161-168.

Birindelli, J. L. O. \& H. A. Britski. 2009. New species of the genus Leporinus Agassiz (Characiformes: Anostomidae) from the rio Curuá, rio Xingu basin, Serra do Cachimbo, Brazil, with comments on Leporinus reticulatus. Neotropical Ichthyology, 7(1): 1-10.

Birindelli, J. L. O., L. M. Sousa, A. L. Netto-Ferreira, N. Lujan \& M. H. Sabaj Pérez. 2009a. The Pipe expedition: relatos da expedição à Serra do Cachimbo. Boletim SBI, 95: 10-15.

Birindelli, J. L. O., A. M. Zanata, L. M. Sousa \& A. L. NettoFerreira. 2009b. New species of Jupiaba Zanata (Characiformes: Characidae) from Serra do Cachimbo, with comments on the endemism of upper rio Curuá, rio Xingu basin, Brazil. Neotropical Ichthyology, 7(1): 11-18.

Costa, W. J. E. M. 1994. Description of two new species of the genus Moenkhausia (Characiformes: Characidae) from the central Brazil. Zoologischer Anzeiger, 232: 21-29.

Eigenmann, C. H. 1917. The American Characidae. Part I. Memoirs of the Museum of Comparative Zoology, 43: 1-102.

Ferraris, Jr., C. J. 2007. Checklist of catfishes, recent and fossil (Osteichthyes: Siluriformes), and catalogue of siluriform primary types. Zootaxa, 1418: 1-628.

Fink, W. L. \& S. H. Weitzman. 1974. The so-called cheirodontin fishes of Central America with description of two new species (Pisces, Characidae). Smithsonian Contributions to Zoology, 172: 1-46.

Géry, J. 1977. Characoids of the World. Neptune City, T. F. H. Publications, 672p.

Géry, J. 1992. Description de deux nouvelles espèces proches de Moenkhausia lepidura (Kner) (Poissons, Characiformes, Tetragonopterinae), avec une revue du groupe. Revue française d'Aquariologie et Herpetologie, 19(3): 69-78.

Goulding, M., R. Barthem \& E. Ferreira. 2003. The Smithsonian atlas of the Amazon. Washington, Smithsonian Books, 253p.

Lima, F. C. T. \& J. L. O. Birindelli. 2006. Moenkhausia petymbuaba, a new species of characid from the Serra do Cachimbo, rio Xingu basin, Brazil (Characiformes: Characidae). Ichthyological Explorations of Freshwaters, 17(1): 53-58.

Lima, F. C. T., H. A. Britski \& F. A. Machado. 2007. A new Moenkhausia (Characiformes: Characidae) from central Brazil, with comments on the area relationship between the upper rio Tapajós and upper rio Paraguai systems. Aqua, International Journal of Ichthyology, 13(2): 45-54. 
Lima, F. C. T. \& M. Toledo-Piza. 2001. New species of Moenkhausia (Characiformes: Characidae) from the rio Negro of Brazil. Copeia, 2004(4): 1058-1063.

Lima, F. C. T. \& J. S. Zuanon. 2004. A new Astyanax (Characiformes: Characidae) from the rapids of the lower rio Xingu, Brazil. Neotropical Ichthyology, 2(3): 117-122.

Lucinda, P. H. F., L. R. Malabarba \& R. C. Benine. 2007. On a new species of the genus Moenkhausia Eigenmann (Ostariophysi: Characidae). Zootaxa, 1525: 61-68.

Menezes, N. A. \& S. H. Weitzman. 1990. Two new species of Mimagoniates (Teleostei: Characidae: Glandulocaudinae), their phylogeny and biogeography and a key to the glandulocaudin fishes of Brazil and Paraguay. Proceedings of the Biological Society of Washington, 103: 380-426.

Mirande, J. M. 2009. Weighted parsimony phylogeny of the family Characidae (Teleostei: Characiformes). Cladistics, 25: 574-613.

Sabaj Pérez, M. 2009. PIPE-Expedition in die Serra do Cachimbo. Amazonas, Süßwasseraquaristik-Fachmagazin, Natur und TierVerlag GmbH, 25: 36-43.

Taylor, W. R. \& G. C. van Dyke. 1985. Revised procedures for staining and clearing small fishes and other vertebrates for bone and cartilage study. Cybium, 9(2): 107-119.

Accepted March 19, 2010

Published June 25, 2010 